\title{
Contestation of Discourse on Alcoholism among Native Americans in Joy Harjo's The Reckoning (2002)
}

Shofi Mahmudah Budi Utami

Jenderal Soedirman University

shofimahmudah@live.com

Article History:

First Received:

$03 / 11 / 2020$

Final Revision:

$18 / 12 / 2020$

Available online:

$30 / 12 / 2020$

\begin{abstract}
This study aims at revealing how the discursive practices and the discourse on alcoholism in the Native Americans is produced and contested in a short story entitled The Reckoning by Joy Harjo. The problem in this study is approached by Foucauldian concept of discourse production procedure. The method applied here is the Foucauldian discourse analysis by examining the problem through the process of formation including external and internal exclusion. Central to the analysis is that alcoholism is produced as taboo through the mother character which limits the general understanding about alcoholism; hence this discourse is possible to produce by the subject whose credentials can validate the truth. This discourse is also affirmed by the contextual prohibition which authoritatively can state the truth about alcoholism. This is further contested in the current society of how being an alcoholic would be considered as a nonnative American way of life. The result indicates that alcoholism among Native American society becomes the discourse within which constraints produce considerable barriers to expose or address to this topic.
\end{abstract}

Keywords: alcoholism, discourse, discourse analysis, discursive practice, native American

\section{http://jos.unsoed.ac.id/index.php/jes}

\section{INTRODUCTION}

This paper will discuss a short story by a Native American writer, a wellknown Native American poet named Joy Harjo, entitled The Reckoning. This work is published in a collection of short stories written by Native American writers. Among the other Native American writers whose works published in this collection, Joy Harjo is one of the authors with the Muscogee Creek heritage-a Native American tribe in the northern America. Although Joy Harjo is also of Canadian descent, she tends to be more upholding her tribal values and acknowledging her native blood. Therefore, the works that Joy Harjo produced are heavily influenced by her tribal values. From the works she has produced such as poetry, short stories, and novels, confirm her consistency in creating such 
intriguing works to relate to her cultural root. This also contributes to her position as a Native American poet whose merit have recently recognized and honored with many awards in the field of Native American literature in particular and American literature in general. The most recent honor she attained is being chosen to serve the $23^{\text {rd }}$ of the Poet Laureate in 2019 (Charles, 2019).

One of the works popularized in the anthology of contemporary Native American short stories is entitled The Reckoning, published in 2002. What is always interesting about the stories of the Native American works is the relationship between cultural experience and the current situation; more specifically, there are strong characters of Native American tribes about how to interpret nature and their lives. However, the most interesting thing specifically about The Reckoning is the narration of an intriguing story in a flash-back plot that is quite complicated, unlike the works of other Native American authors. In a simple theme, this story offers the reader to not just accept the issues in the story as it is taken-for-granted. With its title "The Reckoning" or which is understood as a "moment to remember", the story leads to a very central issue, namely about alcoholism in the Native American society.

Alcohol abuse or alcoholism seems to cause compounded problems for native Americans (in the northern part in particular) and native people in Alaska (Beauvais, 1998). This kind of image is problematized in the context of native American society. Unfortunately, the native people are also burdened by this 'alcoholic' stereotype. Historically, the indigenous population in the northern America was introduced to the liquor by the European colonists. The native Americans exchanged their highly-sought animal skins with alcohol beverages (Beauvais, 1998). Although some of the Indian tribes were already familiar with and produced weak beers, the effect of the alcohol among the native tribes was still naïve. The indigenous population was not ready yet with these compounded problems such as physical and emotional problem as well as the social problem, the burden of this alcoholic stereotype among the native American society. By viewing this complexity of how alcoholism is located in the discourse of native American society, it further triggers a question of the contestation within this alcoholism discourse, which is of course situated in the context of the native Americans. Thus, this article will examine further of how the discourse of alcoholism in the short story The Reckoning was produced and reproduced in the Native American society.

\section{Discursive formation and discourse production}

According to Foucault, discourse can refer to any statement or expression that has meaning and effect. The statement or expression can be in the form of a grouping; that is, like a more general thing, for example "masculinity", so the statement or expression is not only classified as a sentence. However, what Foucault emphasizes about discourse is not the text (statement or expression), but rather how the text is produced to shape the knowledge to construct a certain grouping if it is referring to only one object (Foucault, 1976).

Discourse can be seen as a term that refers to statements, the rules that are formed from these statements and the process by which these statements are circulated and other statements are excluded. 
Thus, discourses should be seen as groups of statements which are associated with institutions, which are authorized in some sense and which have some unity of function at a fundamental level. The statement can be seen as an authorized proposition or action through speech (Mills 1997). The statement is not simply a sentence because, for example, a map or image could be taken as a statement. The critics, Hubert Dreyfus and Paul Rabinow, argue that 'Maps can be statements, if they are representations of a geographical area, and even a picture of the layout of a typewriter keyboard can be a statement if it appears in a manual or as a representation of the way the letters of a keyboard are standardly arranged'. (Mills, 2003, p. 65)

This excerpt emphasizes that statement does not necessarily include words or textual data but rather, as Dhona also highlighted, statements comprise its entire dimension making it one unity called discourse (Dhona, 2020). Therefore, to consider a statement as a discourse, it is needed to also look at its genealogy and power relation which Halwati tends to dismiss in her article (Halwati, 2015).

Discourse is not left unchecked, but there are those who play a role in controlling over these discursive practices. Thus, discourse is often associated with power as Hook also emphasizes that "...discursive rules are hence strongly linked to the exercise of power" (Hook, 2001). Discourse is constituted by social system including domination which has the power to oppress (Fismatika, 2018). In this sense, discourse is not as simple as equating it with a language by looking at the relationship between discourse and reality. Discourse subsumes a system that shapes how to see a reality. It is because the word or sentence does not associate with what is known (certain knowledge), but rather, it associates with constraints (what it constrains) and formation (what it is perceived) (Hook, 2001). The practice to perpetuate a discourse is the regularity.

"A practice that imposes on them; it is in this practice that the events of discourse find the principle of their regularity... Thus, the regularities which we perceive in realities should be seen as the result of anonymous regularities of discourse we impose on reality" (Mills, 2003, p. 56)

The regularities, in this sense, refer to constraints or prohibition. Foucault also mentions that regularities, within the mechanism production of discourse, are realized namely by exclusion. This exclusion corresponds to social procedures in the form of prohibition (Hook, 2001; Faruk, 2012). The external systems of exclusion include "taboo, the different between mad and sane, and the distinction between true and false" (Mills, 2003, pp. 57-58); or also refer to objective prohibitions, subjective prohibitions, and contextual prohibitions (Faruk, 2012, p. 242).

These three kinds of external exclusion cause a process of how discourse exists in society. For example, something or the object in question is limited; taboos limit the way people know what they know. Secondly, not everyone can talk about certain things; it relates to the exclusive rights of the subject; one example is a person who is mentally unwell, what he or she says will not be considered or heard. The third is about right and wrong or contextual prohibitions, namely 
dealing with the prohibitions that are usually found in rituals, or Foucault mentions where the power sees "expert" to determine right and wrong; truth is something that is supported materially by various practices and institutions (Mills, 2003, p. 58). For example, someone's statement will be considered true if it is appropriate, it fits with other valid statements in a society.

Apart from these external exclusions, discourse is also formed and produced through an internal exclusion which, according to Foucault, consists of four things:

Foucault also asserts that there are four internal procedures of exclusion and these are: commentary; the author; disciplines; and the rarefaction of the speaking subject. These procedures are all concerned with classifying, distributing and ordering discourse, and their function is ultimately to distinguish between those who are authorized to speak and those who are not-those discourses which are authorized and those which are not. The first internal exclusion, commentary, is writing about another's statements. Thus, literary criticism can be considered to be commentary. (Mills, 2003, pp. 58-59)

As mentioned in the above quote, four things in the internal exclusion system also have the same function, namely controlling and restricting the discourse. This procedure is needed because the discourses themselves exercise their own control (Faruk, 2012, p. 244). For example, many people think that a text is commented on and discussed because the text is interesting and more appreciated than other texts. The role of the commentary or comment is to say what in the text is, what the text has been modified to, retold, and repeated. Then a new discourse which is linked to a more present era emerges. Later on, this discourse is infinitely transformed and repeated; it recurs over and over. Therefore, the commentary makes discourse in circulation so that it is in the same function and the principle of continuous differentiation (Mills, 2003; Faruk, 2012). In this way it allows the generation of new discourses.

The second principle is the author. It means that the author here is not the individual speaking, writing the text, but rather grouping the discourse. For example, a certain author produces many books from which it produces a relation between these books. This text is then seen as a reaction to another text. Although the author may be attributed to the discourse, it does not only relate to only one author. An example is in the quote below:

Foucault is very critical of such notions as the progression of an author from immaturity, early works to maturity or later works. If we discuss the 'early' works of Shakespeare, we should interrogate why it is that we are using such a metaphor, implying as it does that these works are less developed than his later texts, and we should simply analyze these texts in their own terms, rather than according to a fictional schema which we have of Shakespeare's life. (Mills, 2003, p. 60)

Authors are asked to take into account the unity of the text on their behalf; to carry the authentification of the hidden meanings in his work; to link their work to personal experience or history that led to the birth of the work. Here the author 
becomes the point of coherence aside from their creative or originating capacity. This coherence point has discursive function to the existence of the discourse and the affirmation of their status in a given society (Hook, 2001).

The next principle of internal exclusion is disciplines. This limitation is located in the subject matter, or the thing discussed. A discipline must allow the formulation of new statements; take what is said to be right or wrong-this is where the principle of constraint is realized (Faruk, 2012). Through a certain set of methods and approaches, a text has been limited to discussing only certain things; because the discipline has a set of propositions and rules that are considered factual to produce new proportions or new statements about true or false. The last principle of internal exclusion is the rarefaction of the speaking subject. This is a limitation on who has the right to speak; some discourses are open to everyone and some are constrained. In this sense, Foucault makes us aware of the presence of the limits within which we speak (Hook, 2001).

Based on the discourse production procedure both externally and internally, it can be understood that not all discourses are open to everyone; limitations in the form of prohibitions or regulations determine between right and wrong. All these existing procedures keep the discourse in circulation, that is, it is retold, passed down, modified and distributed in a given society. Ritual, discourse society, doctrine, and social appropriation can be interrelated and form a large type of knowledge that ensures the distribution of subjects speaking into different types of discourse (Faruk, 2012, p. 250).

\section{RESEARCH METHOD}

This is a study of how the discourse on 'alcoholism' among the native American society is produced and contested through a short story entitled The Reckoning written by a native writer. To approach this problem, this study is framed by using Foucauldian discourse analysis which is also a method of understanding discursive practices through the subjects of knowledge (Arribas-Ayllon \& Walkerdine, 2008). This method helps to examine this problem centered on the focal points of experiences along with Foucault's axes on knowledge, power, and subjectivity. Based on the following critical frameworks, the textual data are then selected and grouped. Specifically, the textual data is in relation to which it tries to illustrate a native people who is seen as drunkard, and presents how the understanding of alcoholism is formed and perceived within native American people. Second, through the context of the Native American society this explores the understanding of their history related to this unfortunate stereotype of being alcoholic. Finally, these selected textual data are then analysed by using the Foucauldian discourse concept by subsequently explaining the mechanism or procedure of discourse production including external and internal exclusion within the story. The discourse on alcoholism is then understood how it is produced and contested in the Native American society through the story.

\section{RESULT AND DISCUSSION}

The Reckoning tells of a character by its narrator, 'I' who is a Pueblo, an Indian tribe who lives in the southern United States, married to an Indian tribe named 
Larry. The narrator as the central character lives in a family that still upholds her tribal values. Even so, the father of the narrator was a drunkard who often hurt his children and wife. Since the narrator was a young girl, her mother always reminded her about to not get wet when washing dishes otherwise she will marry a drunk (Harjo, 2008, p.175). However, the narrator doubted what her mother said; and every time the narrator washed the dishes, the clothes she wore were always wet. In the end, after the narrator grew up, she met a young Indian, who was handsome, smart, and an artist (jewelry maker). After knowing him several times, they finally got close, and decided to get married. Even though she knew that the young man was a drunkard, the narrator loved him anyway. Over time, she reminisced about her father's treatment to her mother, brother, and herself, as well as the words her mother used to say to her about drunkard.

In this short story, we can see how the view of being an alcoholic or alcoholism problem is considered wrong, which is taboo. Beside it is mentioned by the narrator's mother about the superstitious thought of marrying a drunk, the narrator also reassures herself that her mother's words eventually proved the truth, confirming that her mother wants to keep her away from 'alcoholism'. This is shown when the narrator realized that Larry was a drunkard and was hurt by Larry, so that she felt ashamed to call her mother telling all about it (Harjo, p.177178). As Foucault stated, discourse does not just appear, or naturally, as it is. Discourse exists because it is produced by a given society; and even that discourse is selected, controlled, and distributed through the production procedure of the discourse. The alcoholism that appears in The Reckoning gives a consciousness that the text about 'alcoholism' is exercised in order to determine whether it is right or wrong to become a drunkard.

\section{Subjective Prohibition: between mad and sane}

Based on the principle of external exclusion, discourse is formed through constraints that limit the perspective of what society actually already knows. The first is subjective prohibition, as stated by Mills that subjective prohibition refers to who states, between mad and sane, that is centered on the subject; so that it concerns with the right to speak about everything (Mills, 2003). Statements of insane (mad) or mentally ill people are not considered, are not believed. Rejection of the truth witnessed by a madman makes them not entitled to state or speak about everything.

In The Reckoning, this subjective prohibition can be seen from the characters including 'mother' and Larry's sister, 'father' and Larry. 'Mother' character or the mother of the narrator of the story is described as a sane person. This person, who is not considered crazy, has the right to speak; and thus what is said is not denied. Like what the narrator's mother once stated about alcoholism, namely by limiting the subject of what is known about alcoholism. The mother character implies that alcoholism is something that crazy people do and it makes them crazy or not sane. With the constraints (prohibitions) given to the narrator about alcoholism, the mother character has a desire to keep the narrator away from alcoholism as well as the crazy people.

Statements like "Don't get your dress wet like that; it means you'll marry a drunk" (Harjo, J, 2008, p. 175), this gives the discourse on alcoholism being carried 
out by a madman, while the "mother" is sane, so are her children; therefore, the desire to limit her 'sane self' from the mad is expressed. Apart from the expression of desire, discourse also implies power. The mother character has the right to state or produce the discourse because she has power. As Foucault states that power is influenced by knowledge, the mother character has knowledge of what she understands about the world; she has her own worldview to make sense a thing. The mother character is a member of the council of Indian tribal groups in Pueblo (California) and also a teacher at the school; she is an elected tribal official and she teaches Sunday school every week. She has a mission in her small world that she wants to make sure there are rules and that they are enforced (Harjo, J, 2008, p. 176). The knowledge gained as a person who still preserves his Indian tribal values, the mother character understands how alcoholism is not culturally appropriate in native American society and particularly as being a Pueblo.

As an educator also has knowledge of how alcoholism can risk health. Additionally, as a mother, who is married to an alcoholic man, she understands that alcoholism fuels domestic violence, just as she experienced. This knowledge positions 'mother' as the subject who has the right to state or speak about alcoholism. A statement from a sane person, what the mother character speaks about, will not be rejected. It is understood as an apparently natural thing to say so. It is here that the discourse on alcoholism takes shape. The discourse on alcoholism is produced by limiting the understanding of what people have known about and through the axis of power that the mother has, the statement on alcoholism seems to be adequately validated.

However, what the mother character calls out to the narrator about alcoholism is not taken for granted. The narrator is in a position to accept the discourse, but at the same time she tries to explore the discourse. When the narrator knows that her clothes are always wet when washing dishes, the narrator does not necessarily limit herself from the 'wet clothes', but she just lets herself get wet. Even at the end the narrator eventually is married to a drunk, she does not immediately relate what her mother has shouted at her. However, the words that the mother character once told the narrator are repeated by the implication of the fate the narrator has; and this seems to be connected to their present state as the truth. In this position, the discursive practice is realized and the discourse is produced.

However, in the midst of the narrator's exploration of the existing discourse on alcoholism, she confronts herself with the memories she shared with her father and Larry (who are both as drunkards). This scene in the story shares her experience in her childhood when her father got drunk and beat her mother, brother, and herself. She believes what her father told her as if it confirms the statement of a mad person,

If I followed the source it would slam me back into childhood, to my father staggering in drunk, beating my mother, the shame and hate in burning, burning. Then he'd hit my brothers. And then me whom it was said he loved most. He'd save me for last, when his anger was ashes, when the fire was hottest. And then he'd hold me, "Sugar, Sugar" he'd croon, the tears so thick they made a lake on the linoleum floor. (Harjo, J, 2008, p. 176) 
Even though the narrator was beaten, but she did not simply reject the discourse of alcoholism; the narrator believed she was the most beloved child, even her father called her "sugar"; her father also finally saved her from the beatings. These things become a deferral point where the drunk is perceived as the mad person; otherwise the narrator sees that the drunk is also in a sane position too by relating it to the love she got from her father. Just like Larry who is married to the narrator, she understands that Larry loves her even though sometimes the domestic violence happened to her as well. The line between mad and sane here is finally blurred, because even the crazy does the same as the sane people do; what her father and Larry said to the narrator is then not considered 'mad'.

The subjectivity that produces discourses on alcoholism is eventually contested, between the boundaries of the subject which is mad and sane. Discourse on alcoholism is formed from subjects who have the right to speak about alcoholism. Even though at the end the discourse is not taken for granted because there are subjects who are considered 'mad' but in fact they are beyond the boundaries of mad and sane. Hence, the boundary is blurred; the discourse is thus against itself.

\section{Objective Prohibition: taboo}

Taboo is a prohibition that makes it not arbitrary to speak about and it also limits how people speak about the object or thing; taboo is a form of prohibition since it makes it difficult to speak about certain subjects such as sexuality and death and constrains the way that we talk about these subjects (Mills, 2003, p. 58). The object or thing that is discussed becomes the goal as well as makes it a contestation. As it is described in The Reckoning about alcoholism, the object in the discursive formation is alcoholism; so that the purpose of the discourse that is constructed is about alcoholism. Meanwhile, the conflict is merely about the object itself namely things related to alcoholism.

The boundary of the object discussed is then formed, distributed, and contested. When the discourse limits the things that are discussed, this also indirectly makes the object no longer discussed carelessly. If alcoholism is positioned as a taboo, it means that not all conversations can be linked to this object; and the clearer the boundary is the stronger the discourse will be. As exemplified in The Reckoning short story, particularly in the following statement: "Don't get your dress wet like that; it means you'll marry a drunk" (Harjo, J, 2008, p. 175), when the object discussing about alcoholism is then linked to the innocence of a young girl, who did not yet understand alcoholism in her lives. In this case, it can be seen how 'alcoholism' becomes a limitation or constraint to the world of children, it is taboo to be discussed with children; but at the same time it is contrasted with the world of this innocent child. Alcoholism is something that cannot be discussed carelessly in particular with the children. Therefore, this discourse on alcoholism limits this innocence as well as contrasts with innocence itself.

\section{Contextual Prohibition: true and false}

Contextual prohibitions have to do with rituals that justify and blame something. A statement will be true if it is validated with other statements that are in accordance with what is in the society, such as according to certain rituals. The 
context here also relates to institutions; wrong and right related to the institution that ratified it. In The Reckoning, it shows how the cultural values of Indian tribes are still preserved by the native American.

Before the native Americans were colonized by Europeans, they produced and used alcohol beverages only as part of their rituals, such as for the purposes of their ceremonies. By then, alcohol was introduced by the European people as an exchange for agricultural products and animal skins produced by the native Americans. Initially, the alcohol produced by the native Americans was low-grade alcohol from a process of plant fermentation such as berries, grapes, corn, cactus plants, etc.

In the Southwestern U.S., the Papago, Piman, Apache and Maricopa all used the saguaro cactus to produce a wine, sometimes called haren a pitahaya. Similarly, the Apache fermented corn to make tiswin (also called tulpi and tulapai) and the yucca plant to make a different alcoholic beverage. The Coahuiltecan in Texas combined mountain laurel with the Agave plant to create an alcoholic drink, and the Pueblos and Zunis were believed to have made fermented beverages from aloe, maguey, corn, prickly pear, pitahaya and even grapes. (Melissa, 2013)

To the east, the Creek of Georgia and Cherokee of the Carolinas used berries and other fruits to make alcoholic beverages, and in the Northeast, "there is some evidence that the Huron made a mild beer made from corn." In addition, despite the fact that they had little to no agriculture, both the Aleuts and Yuit of Alaska were believed to have made alcoholic drinks from fermented berries. (Abbott, 1996)

It is mentioned in the above quotations how native people have known alcohol even though in their traditional way, but since the trade was carried out with the Europeans, high levels of alcohol were introduced and these high-level alcohol beverages are not related to the uses for their ritual purposes, instead it is for daily consumption as exemplified by the Europeans to American Indians.

Unlike other cultures that have ingested alcohol for thousands of years, the relationship between indigenous Americans and alcohol is relatively new. Native Americans have had fewer centuries to develop the genetic tolerance to alcohol that is present in other ethnic groups. Mix in poverty and living with ongoing oppression, and alcohol contributes to a state of emergency on many reservations. (Abbott, 1996)

With the influence of the European people and the lack of knowledge about the use of high-level alcohol, many of these American Indians slowly lost their roots to their tribal cultural values. In addition, this culture of alcoholism also hit Indians, both those who were on reservation and those who were not, so that many were stricken with an extreme addiction and poisoning at that time. 
“...the hard-drinking, rowdy colonists provided early Native Americans with the worst role models possible. Binge drinking, violent outbursts and extreme intoxication were common. This influence had a devastating effect on Native American communities." Some possible causes include the loss of culture and autonomy, which have included being forced onto reservations and a variety of other indignities great and small. (Melissa, 2013)

Thus, what the mother character said to the narrator gives a truth to what she claims about alcoholism. She is in a right position of stating the truth; the position of mother here has the power, namely as an 'expert' on Indian cultural values; as mentioned in the short story that she is an official in the Indian tribal community. Stating a truth is also institutional, which is supported by certain institution as Foucault emphasizes "... truth is something which is supported materially by a whole range of practices and institutions: universities, government departments, publishing houses, etc." (Foucault, 1976). Institutionally, the truth stated by the mother is supported by her credential. The knowledge that the mother had during her tenure as a leader in the Indian tribal community gave the validity of what she said. The truth is supported by the knowledge and position that has the power to put the truth into something that is accepted in the context of native American society, that alcoholism is not a part of native American culture. Thus it needs to be kept away from those of the 'mad'.

Then the discourse on alcoholism that has been formed is then supported by other justifications in terms of other disciplines such as scientific disciplines. As Foucault mentioned earlier about the commentary, there are other truths that are formed to repeat the existing discourse, refine it, and redistribute it to the society of the discourse (Foucault, 1976; Faruk, 2012; Jaya, 2016). Another discourse on alcoholism is supported by medical facts in the medical field (according to the medical discipline), that the American Indians are more prone to afflict with mental disorders due to drinking high-level alcohol beverages because they do not have enzymes which is functioned to metabolizing these substances in the body; the Native Americans have a lack of the necessary enzymes to properly metabolize alcohol (Abbott, 1996), and therefore, have no genetic defense to protect them from becoming alcoholics. This truth supports the discourse about alcoholism that alcoholism will give a worse impact on the American Indians than those of European people.

\section{CONCLUSION}

The discursive practices on alcoholism in the Native American people are expressed by the mother character in The Reckoning. Here, the mother wants to keep her daughter away from the drunks; the discourse is thus formed by limiting the understanding toward this topic, about alcoholism. This constraint on alcoholism further positions it as something taboo, which also limits it to be discussed carelessly. In other words, alcoholism cannot be discussed anytime with any people in order to lessen the exposure on this topic. The mother character also becomes a potent subject to produce this discourse as she is a member of tribal community; thus the truth on alcoholism that risks the life of American Indian community is authenticated contextually; that this is out of their tribal values. This 
interrelated concept of discursive practice and discourse production is further understood as the constraints to the understanding of the American Indian identity as well. Reconsidering such issue on identities that Native American literary works are strongly adhered with, this study is expected to be able to encourage more research in Native American literary works by developing more recent methodology that can enrich the studies on Native American literature including FDA (Foucauldian Discourse Analysis). As it is also suggested by Nonhoff that FDA is potential to give alternative in critical analysis and reshape a new understanding of a certain matter (Nonhoff, 2017; van der Wath, 2019).

\section{REFERENCES}

Abbott, P. J. (1996). American Indian and Alaska Native Aboriginal Use of Alcohol in the United States. American Indian and Alaska Native Mental Health Research doi: 10.5820/aian.0702.1996.1, 7(2), 1-13.

Arribas-Ayllon, M., \& Walkerdine, V. (2008). Foucauldian discourse analysis. In C. Willig, \& W. Stainton-Rogers, The SAGE handbook of qualitative research in psychology (pp. 91-108). London: SAGE Publications Ltd doi: $10.4135 / 9781848607927$.

Beauvais, F. (1998). American Indians and alcohol. Alcohol health and research world, 22(4), 253-259.

Charles, R. (2019, June 20). The Washington Post. Retrieved October 28, 2020, from The Salt Lake Tribune: https://www.sltrib.com/artsliving/2019/06/20/native-american-writer/

Dhona, H. R. (2020). Analisis Wacana Foucault Dalam Studi Komunikasi. Journal Communication Spectrum, 9(2), 189-208.

Faruk. (2012). Metode Penelitian Sastra: Sebuah Penjelajahan Awal. Yogyakarta: Pustaka Pelajar.

Fismatika, V. (2018). Wacana Kekuasaan dalam Bentuk Kumpulan Cerpen Seekor Bebek yang Mati di Pinggir Kali Karya Puthut E. A. (Kajian Analisis Wacana Kritis Michel Foucault). Diglossia, 9(2), 59-70.

Foucault, M. (1976). The Archelogy of Knowledge. (E. A. Iyubenu, Ed., \& I. R. Muzir, Trans.) New York: Harper \& Row Publisher.

Halwati, U. (2015). Analisis Foucault dalam Membedah Wacana Teks Dakwah di Media Massa. AT-TABSYIR Jurnal Komunikasi Penyiaran Islam, 1(1), 145158.

Harjo, J. (2008). Reckonings: Contemporary Short Fiction by Native American Women. (H. D. Wong, L. S. Muller, \& J. S. Magdaleno, Eds.) Oxford and New York: Oxford University Press.

Hook, D. (2001). Knowledge, materiality, history: Foucault and discourse analysis (online). LSE Research online, 1-50.

Jaya, A. (2016). Produksi, Distribusi, dan Kontestasi Wacana Tradisi dan Modernitas dalam Cerpen Leteh Karya Oka Rusmini. Poetika, 107-118.

Melissa. (2013, November 18). Myths and misconceptions. Retrieved September 13, 2015, from Ioday I found out: http://www.todayifoundout.com/index.php/2013/11/native-americansintroduced-alcohol-europeans/ 
93 J-Lalite: Journal of English Studies Vol.1, No.2, December, 2020

Mills, S. (2003). Routledge Critical Thinkers: Michel Foucault. London and New York: Taylor \& Francis group.

Nonhoff, M. (2017). Discourse Analysis as Critique. Palgrave Communication, 3, 111.

van der Wath, A. (2019). Women exposed to intimate partner violence: a Foucauldian discourse analysis of South African emergency nurses' perceptions. African Health Sciences, 19(2), 1849-1857. 